\title{
Formation of Regional and Civic Identities in Modern Russia Through Activities of National- Cultural Associations Taking the Republic of Bashkortostan as an Example
}

\author{
Elvira Anvarovna Mukhtasarova \\ Department of Humanities and Socio-Economic Sciences \\ Ufa State Petroleum Technological University, Branch of \\ the University in the City of Oktyabrsky \\ Oktyabrsky, Republic of Bashkortostan, Russian Federation \\ E-mail: mux.elvira@yandex.ru
}

\author{
Fail Gabdullovich Safin \\ Department of Ethnopolitology \\ Institute of Ethnological Studies of R.G. Kuzeev Ufa \\ Scientific Center, Russian Academy of Sciences \\ Ufa, Republic of Bashkortostan, Russian Federation \\ E-mail: failsafin@mail.ru
}

\begin{abstract}
- the article discusses the issue of development of civic identity and civic community in controversial, ambiguous conditions of transformation and modernization relevant for modern Russia. One of the important ways of identity formation is activities of national-cultural associations in the national regions of the Russian Federation. The issue is analyzed on the example of the Republic of Bashkortostan as a multinational (multi-ethnic) region that has accumulated positive experience. The main public institutions implementing republican government policies in interethnic relations are the Executive Committee of the World Kurultai Bashkirs and the Assembly of Peoples of the Republic of Bashkortostan combining activities of national associations. In 2015, the federal national-cultural autonomy of the Bashkir was created to strengthen civil society. At the same time, there are significant problems: contradictions in ideological positions and demands of associations of the most numerous peoples of the republic - the Bashkir and the Tatar; relative formality of concepts and activities of the Assembly and the Kurultai Executive Committee and weak feedback. The socioeconomic instability has been caused by long transformation and modernization of Russia. Opinion polls show the increase in civic identity in the region. But this indicator may be situational. In the context of Russia's traditional multinationality (multiethnicity), national-cultural associations remain an important agent in the formation of civic harmony and civic identity.
\end{abstract}

Keywords - civic identity, civic community, social representations, national-cultural associations, national identity, republican identity.

\section{INTRODUCTION}

Development of civic identity in modern Russia is associated with the tasks of consolidating society. A multinational or multicultural society is traditional. The conditions of globalization and modernization changed the ethno-national structure and weakened the position of ethnonational, national-cultural and regional identities. Due to socio-economic instability and uncertainty of nation-building, these changes can be situational [9]. Modern conditions increase the requirements for civil interaction and consent of members of society, responsibility and freedom of personal choice. The tasks of developing civic identity ensure integration and integrity of self-identity of a person as a citizen of multinational or multicultural society by developing a system of universal moral values, taking into account diversity of social attitudes and norms [15].

\section{MATERIALS AND METHODS}

On the basis of historical and sociological methods and taking into account peculiarities of the ethno-national structure and the ethno-political situation in Bashkiria, the article reveals the role of state policy and national-cultural associations in development of regional and Russian identities, ultimately leading to the formation of a single civic community in Russia. The data of sociological surveys conducted in the Ural-Volga region from 1993 to 2017, as well as data of sociological surveys conducted in Bashkiria in August 1995 and January 2014 were used. Documents of public or national-cultural associations of three most numerous peoples of the republic - Russian, Bashkir and Tatar - were analyzed.

According to V. Tishkov, the idea of a united nation is the key to ensuring stability and harmony. The primacy of civic identity over ethno-national is unshakable, no matter how it is disputed by ethno-nationalists. These two forms of community are not mutually exclusive [5]. In modern states, multiple identities are recognized both at the level of collective community and at the level of an individual.

The famous Russian politician and scientist A. G. Asmolov defines civic identity as a person's recognition of his belonging to the community of citizens on the general cultural basis. It defines civic identity from two different points of view. Firstly, it is the personal awareness of belonging to the community of citizens, which has a significant value for the individual. Secondly, it is a phenomenon of supra-individual consciousness, a sign of civic community, characterizing it as a collective subject. Civil identity as a result of reflection of a community is the highest and most complex level of 
development of its subjectivity. Thus, civic identity has two different aspects [6]. It is advisable to consider civic identity as a conscious process of correlation of a person with a certain community in a specific socio-political context. The degree of understanding of a civic identity in consciousness and behavior of citizens is the main guarantee of consolidation of the community, the possibility of its modernization.

It is necessary to form a new Russian identity. The concept by S. Moskovichi is appropriate. Civic identity is a form of social representation. In the 1960s, the representative of the French socio-psychological school S. Moskovichi proposed a theory of social representations. According to the theory, socially significant representations are created and supported collectively. Collective representations are unconscious. This is a set of concepts, beliefs and explanations that arise in everyday life during interpersonal communication. In modern society, they are myths and belief systems of traditional societies. People selectively perceive information in accordance with shared ideas, but the reality is structured on the basis of these ideas. Thus, representations can be considered as a form of social reconstruction of reality.

The periphery of social representations regarding personality identity is ideas, images formed by purposeful state policy, civil society institutions, in particular and national-cultural associations. Identity, including national one, is the cornerstone of interaction of the population and the authorities [3].

The experience of the Republic of Bashkortostan is of great scientific interest. The national structure of Bashkiria is represented by three largest nations - Russian (36.0\%), Bashkirs (28.4\%), Tatars (24.9\%).

In the modern history of Bashkiria, three stages of formation of identities can be distinguished. The first stage (the first half of the 1990s) is formation of national identity. The second stage is formation of republican identity (second half of the 1990s). The third (since 2000) stage is formation of all-Russian identity [1].

At the level of the republican government, the issue of formation of republican identity has been given serious attention since the mid-1990s. During this period, national movements and associations of the Bashkir and Tatar entered a period of crisis, lost mass support from the represented peoples, but still retained influential positions in the political life of the region. In the conditions of republican sovereignty and compromise with federal authorities, radical ideas and demands of national movements were no longer welcomed. They began to be considered destructive. In order to stabilize interethnic relations, pro-government national organizations (associations) were created [13]. At the same time, given the continuing ethnomobilizing potential of national associations, the republican government sought to enlist their support in order to legitimize its course.

At the initiative of the official authorities of the republic, in 1995 the first World Kurultai Bashkir (WKB) was convened. In 1993, Bashkir public associations took the initiative in holding it, voicing radical nationalist ideas. For this reason, the composition of the Kurultai organizing committee was not agreed with the leading Bashkir association of the Bashkir People's Center "Ural" (BSC "Ural"). The chairman of the BSC "Ural" was included in the organizing committee as an ordinary member. The chairman of the central board of another influential association of the Bashkir, the People's Party of Bashkortostan did not join the organizing committee. The deputy chairman of the organizing committee was "a person who was far from Bashkir affairs" [14].

The preparation for the work of the Kurultai, its activities and decisions, in particular the appeal to the President of Russia and the Russian parliament, indicate its loyalty to the official authorities. The thesis about the right of the Bashkir people to self-determination was present in the program documents of leading Bashkir associations.

Most of the requirements put forward by the Bashkir associations began to be considered by the Executive Committee of the World Kurultai Bashkir (WKB) [10]. The initiative was intercepted by the authorities of the republic. The Executive Committee of the World Kurultai Bashkir was the only public organization in Bashkiria financed from the budget of the republic.

In order to form a republican identity, the Tatar Congress of Bashkortostan was established by the Tatar part of the population at the initiative of the republican leadership, in particular President M. Rakhimov. The first congress was held in June 1997. The Executive Committee of the Tatars was elected. It became a regional organization of the World Tatars Congress, "building its activities in contact and in full cooperation with the official authorities of the Republic." It was decided to develop and implement the republican program "Tatars of Bashkortostan" within the State program "Peoples of Bashkortostan".

In order to consolidate the Russians of Bashkortostan, in 1998, under the leadership of the republican government, the Congress (Council) of Russians of Bashkortostan was convened. It was "a republican public association advocating for the social, national and cultural development of citizens of the Republic of Bashkortostan who consider themselves to be Russians." A distinctive feature of the Council's activities was support of the leadership of the republic [11]

Later, the Kanash of the Chuvashs of Bashkortostan was created.

In 2000, the republican government, seeking to expand the social base of pro-government associations by attracting associations of non-titular peoples, created the Assembly of the Peoples of Bashkortostan. The Assembly, which included national and cultural associations of titular and non-titular peoples was headed by Corresponding Member of the Academy of Sciences of the Republic Professor N. Mazhitov. The congress of the association was held on June 3, 2000 in Ufa [7]. The main goals of the association were to preserve and strengthen international harmony in the Republic and in the Russian Federation, as well as to expand cooperation between federal authorities and national public organizations, assist government bodies, local self-government, and national movements in implementing the national, socio-economic 
policy. On August 18, 2000, the President of the Republic M. Rakhimov issued a decree "On holding the Assembly of the Peoples of Bashkortostan". On December 22, 2000 the first congress (congress) of the public association was held [12].

Activities of pro-government associations became a serious stronghold of the republican government in the late $\mathrm{XX}$ and early XXI centuries and contributed to the formation of republican identity.

A new stage began at the beginning of the XXI century, when the federal authorities decided to strengthen the vertical of power. In July 2010, R. Khamitov was appointed to the post of head of the Republic and the process of common civil identity formation changed. The influence of Bashkir public associations on the policy of the republican government and public processes in the region was limited [8].

The World Kurultai and the Assembly of the Peoples of the Republic have become main public institutions designed to consolidate the peoples of Bashkiria and main initiators of major republican and international events that contribute to the interethnic dialogue, civic unity [2].

\section{In 2019, the 5th congress of the World Kurultai was held.}

The important event in forming a civil community and identity of the Russian authorities was creation of nationalcultural autonomies (NKA) throughout the country. According to the definition of the Article 1 Federal Law of November 4, 2014 , the NCA is a voluntary public organization of citizens of the Russian Federation, relating itself to a particular ethnic group and located outside the historical homeland of people. It is created to independently resolve issues of preserving identity, developing language, education and national culture, strengthening the unity of the Russian nation, harmonizing interethnic relations, and promoting an interreligious dialogue [4]. In fact, they became conductors of public policy.

On December 18, 2015, the Bashkir federal nationalcultural autonomy was created in Moscow. According to the new Head of the Republic Radiy Khabirov, the federal national-cultural autonomy has a great unifying potential and plays an important role in the region and beyond. According to the Head of the Republic, this gives us the opportunity to establish better relations between the regions."

\section{RESULTS}

From 1993 to 2017 in some republics of the Ural-Volga region as multi-ethnic regions of the Russian Federation, large-scale ethnosociological studies were conducted. Survey data show that formation of different levels of identities, including "Russian identity", is influenced by social and ethnocultural policies aimed at understanding of unity with the whole country. National-cultural associations play a major role in this process, if the interests they implement do not contradict the spirit of civil and interethnic harmony.

According to the research results, along with regional identity, all-Russian identity is being formed.

The results of the ethnosociological survey conducted in Bashkortostan in August 1995 showed that more than $60 \%$ of the Bashkir identified themselves only with their republic. Among the Tatars living in the republic, this figure was less than one third; among Russians, it did not exceed $15 \%$. The predominant identity was double identity.

The sociological survey conducted in January 2014 showed the dynamics of the situation in favor of Russian identity. But some researchers argue that the current dynamics in favor of Russian identity may turn out to be situational due to socio-economic instability caused by globalization, transformation and modernization of society.

\section{CONCLUSION}

Thus, according to the data of ethnosociological studies conducted in the Ural-Volga region, over the past 20 years, the ratio of national, regional and civil identities has changed. National and regional (republican) identities began to concede in favor of civilian positions due to the fact that in the early 1990 s, the thesis on the advantages of economic sovereignty was widely advertised in the media. This thesis was promoted and implemented by the national Bashkir-speaking mass media. With the strong vertical of Russian statehood, bringing the basic laws and legislative acts of the republics in line with the Russian ones, as well as changes in the policy of republican governments in favor of the federal authorities, the significance of the all-Russian identity began to increase. As ethno-political history of Bashkiria demonstrates, since the end of the 1980s to the present, the policy of the republican authorities based on the recognition of significance of the ethno-national factor and activities of national-cultural associations as a social guide play a significant role in forming identities, especially in national regions of the Russian Federation.

\section{CONFIRMATION}

The main provisions and conclusions are confirmed by the data of the following ethnosociological studies:

1. The ethnosociological survey on the project "Interethnic tolerance and intra-national solidarity in post-Soviet Russia" was conducted in August 1995. 2184 respondents were interviewed, including 824 Russians, 472 Bashkirs, 614 Tatars and 274 other nationalities. The study was carried out under the leadership of F.G. Safina.

2. The ethnopolitological survey on the research project "Ethnopolitical representations of youth: formation and functioning" was conducted in March 1997 under the guidance of F.G. Safina. 1134 people were interviewed in Ufa: 309 Bashkirs, 473 Russians, 346 Tatars and 6 other nationalities.

3 . The ethnic and sociological survey on the research project: "Modern Ethnic Processes in Bashkortostan: Ethnicity, Identity and Tolerance" was conducted in January 2014. A sample of the study, representative of the entire population of the republic, amounted to 1000 people, including Russians - 36.1\% (361 people), Bashkirs - $29.5 \%$ (295 people), Tatars - 25.4\% (254 people) and other nationalities - $9.0 \%$ (90 people). The population survey was conducted in 11 cities, including Beloretsk Birsk, Davlekanovo, Dyurtyuli, Kumertau, Neftekamsk, Sterlitamak, October, Tuymazy, Ufa, Uchaly, and in the following rural areas: Baltachevskom, Alsheevsky, Miyakinskom, 
Krasnokamsky, Sterlibashevskom, Kuyurgazinsky, Dyurtyuli, Haybullinskom, Tuimazy, Uchalinski and Ufimskoe.

4. The ethnosociological survey on the research project "Social Confidence and Tolerance in a Multicultural Youth Environment" was conducted in February 2014 among the youth of Ufa. The authors are Doctor of Historical Sciences, prof. F.G. Safin, Ph.D. A.I. Fathutdinova (Khaliulina). The head of the study was Ph.D. A.I. Fathutdinova. 621 respondents were interviewed. $35.6 \%$ (221 people) were Russians, $23.7 \%$ (147 people) were the Bashkir, 34.4\% (214 people) were Tatars, and $6.3 \%$ (39 people) were representatives of other nationalities.

\section{References}

[1] A.Yu. Davydov, Utilization of expert systems for screw pump sets with surface drive management vol. 157 pp. 129-133 February.2018 (AIME 2018, 2018).

[2] V. Dilthey, The construction of the historical world in the sciences of the spirit M .: Three squares, 2004, p 419.

[3] R.A. Fahrutdinova, R.R. Fahrutdinov, R.N. Yusupov, "The Model of Forming communicative Competence of Students in the Process of Teaching the English Language" International Journal of Environmental and Science Education. vol. 11. No 6 pp. 1285-1294 2016

[4] H.-G. Gadamer, "Truth and Method: Fundamentals of Philosophical Hermeneutics: Per. with him" Society. ed. and entry. M .: Progress, 1988. p. 704

[5] D. Herwitz, "Fransis Fukuyama and the end of history" South African Journal of Philosophy, vol. 19 iss.3, pp. 222-234, 2000.

[6] M. Hurley, "Ecumenical methodology of forgiveness". Irish Theological Quarterly, vol. 68 iss. 4, pp. 357-377, 2003.
[7] F.N. Kozyrev \& K. Ter Avest, "Religious culture as a school subject. British" Journal of Religious Education, vol. 29 iss. 3, pp. 245-258, 2007.

[8] M. Luyckx, "The transmodern hypothesis: towards a dialogue of cultures" Futures, vol. 31 iss.9-10, pp. 971-982 1999.

[9] E.A. Mukhtasarova, F.G. Safin, "State of modern Russian youth tolerance" European Proceedings of Social and Behavioural Sciences vol. 50. pp. 206-213. April 2018 (RPTSS 2018, p.1464, 2018). DOI: 10.15405/epsbs.2018.12.26.

[10] E. Troeltsch, Die Bedeutung des Protestantismus fur die Entstehung der moderner Welt" Munchen und Berlin: Verlag von R. Oldenbourg, 1928. p.103

[11] K.T. Tyncherov, V.Sh. Mukhametshin \& L.B. Khuzina, "Method to control and correct telemetry well information in the basis of residue number system," Journal of Fundamental and Applied Sciences, vol. 9, No. 2S, pp. 1370-1374, 2017. DOI: 10.4314/jfas.v9i2s.848.

[12] M. Weyembergh, "The liberal ironist, philosophy and the dialogue of cultures" History of European Ideas, vol.20 iss.1-3, pp. 575-580, 1995.

[13] Kh.N. Yagafarova, "Performance analysis of surface reducing gear of rod driven screw pump with involute gearing and Novikov gearing" Advances in Engineering Research (AER) vol. 157. pp. 627-630 February.2018 (AIME 2018, 2018)

[14] R.N. Yusupov, "Individuation as a Key Factor in Modern Social Philosophy. Factors of Regional Extensive Development" Published by Atlantis Press SARL. Advances in Economics, Business and Management Research, vol. 113 pp. 446-449. May-June 2019 (FRED 2019, 2019).

[15] R.N. Yusupov, "Resource of Russian religious and philosophical tradition in constructive relationship with west" European Proceedings of Social and Behavioural Sciences (RPTSS 2018). vol. 50. pp. 14021408, April 2018. (RPTSS 2018, p. 1464, 2018). DOI: 10.15405/epsbs.2018.12.171. 